\title{
Similitud e incomparabilidad divinas en el contexto del debate en torno al primado de la existencia y de la quiddidad en la filosofía islámica tardía
}

\author{
Divine similarity and incomparability in the context \\ of the debate on the primacy of existence \\ versus quiddity in later Islamic philosophy ${ }^{1}$
}

\author{
José BELLVER
}

Universidad de Barcelona

Recibido: $19 / 03 / 2013$

Aceptado: 08/05/2013

\section{Resumen}

Pese a que el islam es generalmente caracterizado como un monoteísmo en el que Dios es absolutamente transcendente, existen corrientes en su seno, generalmente vinculadas al sufismo, en las que se conjuga la transcendencia divina con $\mathrm{Su}$ inmanencia. En el artículo se vincula el debate en torno a la aceptación de la inmanencia divina -sin negar por ello Su transcendencia- con el debate en torno al primado de la existencia y de la quiddidad en la filosofía islámica tardía.

Palabras clave: Dios, transcendencia, incomparabilidad, inmanencia, similitud, existencia, quiddidad, primado de la existencia, primado de la quiddidad, sufismo, filosofía islámica tardía, Suhraward̄̄, Ibn 'Arabī, Ibn Taymiyya, Mullā Șadrā, Sabzawārī

\footnotetext{
${ }^{1}$ Quiero expresar mi agradecimiento al Prof. Ali Asani del Dept. of Near Eastern Languages and Civilizations de la Universidad de Harvard y a la Prof. Sabine Schmidtke, directora de la Research Unit Intellectual History of the Islamicate World del Institute of Islamic Studies de la Freie Universität Berlin, así como a sus respectivas instituciones, por su apoyo durante mis estancias como investigador visitante en las mismas durante las que he redactado partes de este artículo.
} 


\section{Abstract}

Even though Islam is generally considered to be a Monotheist religion in which God is presented as absolutely transcendent, there are Islamic schools of thought, generally linked to Sufism, that hold God's immanence along His absolute transcendence. In this paper, the discussion on God's immanence along His transcendence is linked to the debate on the primacy of existence vs. quiddity in later Islamic philosophy.

Keywords: God, transcendence, incomparability, immanence, similitude, existence, quiddity, primacy of existence, primacy of quiddity, Sufism, later Islamic philosophy, Suhrawardī, Ibn 'Arabī, Ibn Taymiyya, Mullā Șadrā, Sabzawārī

\section{Introducción}

El presente artículo pretende considerar la discusión en torno a la articulación en la teología islámica de los conceptos de transcendencia e inmanencia divinas -que en teología islámica reciben el nombre de incomparabilidad (tanzīh) y similitud (tašbīh) - a la luz del debate en torno al primado de la existencia y el primado de la quiddidad en la filosofía islámica tardía. Si bien la teología islámica afirma de manera inequívoca y universal la transcendencia de Dios, algunas metafísicas del sufismo conjugan transcendencia e inmanencia divinas. Estas metafísicas, como la wahdat al-wuŷūd, o unicidad de la existencia, asociada a la figura de Ibn 'Arabī (m. 638/1240), y la wahdat muțlaqa, o unicidad absoluta, asociada a la figura de Ibn Sab 'īn (m. 668/1270), ${ }^{2}$ han sido anatemizadas por corrientes neo-ḥanbalīes bajo la acusación de hulül, un término con el significado general de unión substancial y particular de encarnación. A su vez, la erudición occidental a menudo ha tachado estas corrientes de panteísmo, un término que carece de una traducción clara en árabe. ${ }^{3}$

El debate en torno al primado de la existencia o de la quiddidad busca determinar si la existencia es lo fundamentalmente real, y por tanto la quiddidad es un

\footnotetext{
${ }^{2}$ Para una comparación de las metafísicas de Ibn 'Arabīe Ibn Sab 'īn, véase la introducción de Michel Chodkiewicz a su traducción de Awḥad al-Dīn BALYĀNĪ. Epitre sur l'Unicité Absolue. Présentation et traduction par Michel Chodkiewicz. París: Les deux océans, 1982.

${ }^{3}$ De hecho, no todas las metafísicas de la wahdat o unicidad en contexto sufí están formuladas de manera que puedan ser tachadas de panteísmo. La wahdat al-šshūd o unicidad del testimonio, defendida por Simnānī (m. 736/1336) y que ejerció una honda influencia en Sirhindī (m. 1034/1624), establece que la unidad entre el Contemplado y el contemplador es sólo aparente y no ontológica. Véase el estudio sobre Simnānī de Jamal J. ELIAS. The Throne Carrier of God. The Life and Thought of 'Alä' ad-Dawla as-Simnānī. Albany: SUNY Press, 1995, p. 63 y ss.; y la discusión entre 'Abd al-Razzāq Qāšānī (m. c. 730/1330) y Simnānī a propósito de la wahdat alwuŷūd en Hermann LANDOLT. "Der Briefwechsel Zwischen Kāšānī und Simnānī über Wahdat al-Wuğ̄ud”. Der Islam, 50, 1, 1973, pp. 29-81. En torno a Sirhindī, véase Yohanan FRIEDMANN. Shaykh Ahmad Sirhind̄̄: An Outline of his Thought and a Study of his Image in the Eyes of Posterity. Montreal y Londres : McGiII-Queen's University Press, 1971.
} 


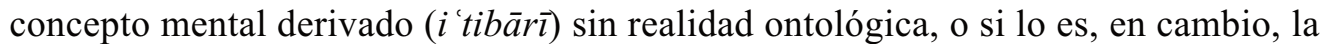
quiddidad, y por tanto la existencia es un concepto mental sin realidad. Este debate, que ha ocupado un lugar central en la filosofía islámica tardía - i.e. la filosofía islámica posterior a Avicena y que no ha ejercido apenas influencia en la filosofía escolástica cristiana -, tiene implicaciones teológicas importantes: si la quiddidad es lo fundamentalmente real, y por tanto el primado pertenece a la quiddidad, Dios será una quiddidad, un ser. Si, en cambio, la existencia es lo fundamentalmente real, y por tanto el primado pertenece a la existencia, Dios será la existencia pura, pues si fuera un ser, sería una realidad compuesta de existencia y quiddidad, o existencia delimitada. Los argumentos que justifican racionalmente el primado de la existencia proporcionan una base para negar las críticas que consideran la wahdat al-wuŷùd como una forma de panteísmo ${ }^{4}$ o de hulül. Sin embargo, estos argumentos racionales no resultarán persuasivos si son considerados desde la asunción inconsciente del primado de la quiddidad.

\section{Similitud e incomparabilidad}

Para comprender la diversidad de sensibilidades en la percepción de Dios en el seno del islam, debe tenerse en cuenta la posición de cada sensibilidad respecto a dos conceptos interrelacionados: (i) la similitud (tašbīh) entre Dios y el cosmos, es decir $\mathrm{Su}$ inmanencia; y (ii) la incomparabilidad (tanzīh) de Dios respecto al cosmos, o Su transcendencia. La percepción que tenga un musulmán de Dios y del cosmos dependerá de su posición respecto a este par de conceptos, lo que determinará su comprensión y vivencia del islam.

Debe subrayarse que todo musulmán, cualquiera que sea su orientación teológica, afirma la absoluta transcendencia e incomparabilidad (tanzīh) divinas. La cuestión no es, pues, si una tendencia teológica en el seno del islam se acerca más a la incomparabilidad en detrimento de la similitud o, viceversa, si acepta la similitud en detrimento de la incomparabilidad. La cuestión es si la incomparabilidad divina se conjuga a la vez con la similitud o no, de modo que podamos hablar a la par de transcendencia e inmanencia divinas, o sólo de transcendencia divina sin inmanencia. Así pues, en el marco del islam, el debate se encuentra en la similitud (tašbīh) del cosmos respecto

\footnotetext{
${ }^{4}$ Por panteísmo entiendo la afirmación estricta de que el universo es Dios. Una definición más amplia tiene el inconveniente de sumir bajo una misma etiqueta posiciones muy diferentes entre sí dificultando la percepción del carácter propio de cada una de ellas. Para una definición más amplia de panteísmo, cf. William MANDER. "Pantheism" en Edward N. ZALTA (ed.). The Stanford Encyclopedia of Philosophy. Invierno, 2012,

$\mathrm{URL}=<\mathrm{http}: / /$ plato.stanford.edu/archives/win2012/entries/pantheism/ $>$.
} 
a Dios. ¿Es la similitud posible una vez se afirma la absoluta incomparabilidad o transcendencia de Dios respecto al cosmos? Y, si lo es, ¿cómo se conjuga la similitud e inmanencia con la transcendencia e incomparabilidad divinas?

El término 'similitud' (tašbīh) ha sido objeto de controversia a lo largo de la historia de la teología islámica. A partir de las discusiones teológicas que acompañaron la aparición de las escuelas mu tazilī y aš arī en las primeras etapas de desarrollo de la teología islámica (kalām), el término 'similitud' (tašbīh) describe aquellas expresiones coránicas en las que se designa a Dios con atributos humanos o en las que Dios aparece caracterizado como si estuviera formado por miembros del cuerpo humano como, por ejemplo, en las expresiones 'la faz de Dios' (Corán 2:15), 'la mano de Dios' (Corán 48:10), etc. En este contexto, el término tašbīh, literalmente 'similitud', cabría traducirlo por 'antropomorfismo'. ${ }^{5}$ La mu tazila ${ }^{6}$ defendió la absoluta transcendencia de Dios y el carácter puramente polisémico o metafórico de estas expresiones, ${ }^{7}$ de modo que no implicaran una pluralidad de atributos en Dios. Los mu'tazilies se opusieron a las posturas de los tradicionistas (ahl al-hadīt) ḥanbalīes, a los que denominaban despectivamente como antropomorfistas (mušabbihūn), y a las posturas de los corporealistas (muŷassimūn), que consideraban que Dios estaba dotado de cuerpo (tâysim ). ${ }^{8}$ Por su parte, los tradicionistas hạbalies afirmaban la literalidad de las expresiones antropomórficas sobre Dios en el Corán y el hadīt , si bien consideraban que los rasgos antropomórficos en Dios no tienen el mismo carácter que en el ser humano. ${ }^{9}$ La respuesta desde el kalām a la crítica mu tazilī vino de la mano de la

\footnotetext{
${ }^{5}$ En torno al concepto de tašbīh entendido como antropomorfismo, cf. Richard C. MARTIN. "Anthropomorphism". Encyclopaedia of the Qur'ān. Leiden: Brill, 2001, vol. I, pp. 103-107 (q.v. Anthropomorphism); Livnat HOLTZMAN. "Anthropomorphism". Encyclopaedia of Islam ${ }^{3}$. Brill Online, 2012. Daniel GIMARET. Dieu à l'image de l'homme. Les anthropomorphismes de la sunna et leur interprétation par les théologiens. París: Cerf, 1997. Binyamin ABRAHAMOV. Anthropomorphism and the Interpretation of the Qur'ān in the Theology of al-Qāsim ibn Ibrāhìm: Kitāb al-Mustarshid. Leiden: Brill, 1996, pp. 1-18.

${ }^{6}$ Para una breve descripción de las tesis de la mu'tazila y un repaso a las distintas interpretaciones de esta escuela en la bibliografía occidental, cf. Massimo CAMPANINI. "The Mu tazila in Islamic History and Thought". Religion Compass, 6, 1, 2012, pp. 41-50.

${ }^{7} \mathrm{Cf}$. Wolfhart HEINRICHS. "On the Genesis of the haqiqqa-majāz Dichotomy". Studia Islamica, LIX, 1984, pp. 111-140; y Marie BERNAND. "La méthode d'exégèse coranique de 'Abd alĞabbār à travers son Mutašābih”. Mélanges de l'Université Saint-Joseph Beyrouth, L, 1, 1984, pp. 85-100.

${ }^{8}$ Durante las etapas de la šì a duodecimana previas a la influencia de la teología mu 'tazilī, algunos grupos defendieron la corporalidad de Dios. Con posterioridad, los karrāmiyya, un grupo originado en Jurasán y que estuvo activo entre los siglos III/IX y VII/XIII, consideraron que Dios es un cuerpo sobre el trono. Cf. Wilferd MADELUNG. Religious Trends in Early Islamic Iran. Albany: SUNY Press, 1988, pp. 39-46.

${ }_{9}^{9}$ Para una relación de expresiones antropomórficas en el Corán y el hadīt según la sensibilidad de los primeros tradicionistas ḥanbalīes, cf. IBN JUZAYMA. Kitāb al-tawhìd wa-ițbāt șifāt alRabb 'azza wa-ŷalla allatī wașafa bi-hā nafsa-Hu. El Cairo: Idārat al-țibā'a al-munīriyya, 1354/1935-36. Para un ejemplo de su respuesta a las tesis mu'tazilīes, cf. p. 16 y ss.
} 
escuela aš arī que afirmó que las expresiones antropomórficas en el Corán y el hadīt tenían un referente real junto a la necesidad de interpretarlas alegóricamente al considerar la esencia divina como absolutamente carente de atributos. Para conjugar ambas posiciones, los teólogos aš arīes recurrieron a la fórmula 'sin cuestionarse cómo' (bi-lā kayfa) tomada de los tradicionistas ${ }^{10}$ por la que se negaba que tales expresiones supusieran atributos físicos en Dios sin cuestionarse cómo ello es posible. Mediante la fórmula bi-lā kayfa buscaron conjugar la literalidad de las expresiones antropomórficas y el tanzīh divino. ${ }^{11}$

En el contexto de las escuelas teológicas del kalām, el término tašbīh se sigue utilizando hoy en día de manera abrumadoramente mayoritaria con el significado de antropomorfismo y con una connotación negativa. Sin embargo, con la irrupción del sufismo especulativo de Ibn 'Arabī (m. 638/1240), ${ }^{12}$ cuya doctrina con el tiempo convendría en llamarse wahdat al-wuŷūd, ${ }^{13}$ o unicidad de la existencia, y que ejerció una honda influencia en la filosofía islámica tardía (ss. XI-XIX), y en particular en filósofos de la escuela de Mullā Șadrā (m. 1050/1640-1), el término tašbīh adquirió también el significado de inmanencia o cercanía divinas. ${ }^{14}$

El concepto de similitud (tašbīh), con el sentido de inmanencia divina, ha sido criticado por autores como Ibn Jaldūn (m. 808/1406) y el teólogo y polemista hanbalī Ibn Taymiyya (m. 728/1328), cuya obra ha ejercido una honda influencia en corrientes como el salafismo y el wahhabismo contemporáneos..$^{15}$ Ibn Taymiyya identifica la similitud divina, en tanto que inmanencia o cercanía divinas y a la que denomina

${ }^{10}$ Cf. Abū l-Ḥasan AL-AŠ 'ARĪ. Maqālāt al-islāmiyyīn wa-ijtilāf al-mușallīn. Ed. Muhammad Muhyyī l-Dīn 'Abd al-Hamīd. El Cairo: Maktabat al-nahḍa al-mișriyya, 1369/1950, vol. I, p. 320.

${ }^{11} \mathrm{Cf}$. Richard M. FRANK. "Elements in the Development of the Teaching of al-Ash 'arī". Le Muséon, CIV, 1991, pp. 141-90 y en particular pp. 155-60.

${ }^{12}$ La bibliografía en torno a Ibn 'Arabī es copiosa. Algunas de las referencias principales son William C. CHITTICK. The Sufi Path of Knowledge: Ibn al-'Arabì's Metaphysics of Imagination. Albany: SUNY Press, 1989; del mismo autor, The Self-Disclosure of God: Principles of Ibn al- 'Arabì's Cosmology. Albany: SUNY Press, 1997; y Claude ADDAS. Ibn 'Arabī ou la quete du Soufre Rouge. París: Gallimard, 1989.

${ }^{13} \mathrm{Ibn}$ 'Arabī no utilizó el término wah̆dat al-wuŷūd para referirse a su propio pensamiento, si bien en al menos una ocasión utilizó una expresión muy parecida en una de sus súplicas que reza: "Te pido, por el secreto con el que unes los opuestos, que reúnas en una unidad todo aspecto que en mí esté disgregado, de modo que pueda contemplar y testimoniar la unicidad de Tu existencia (wahdat wuŷu $\overline{d i}-K a$ )". Para la traducción inglesa, vid. IBN 'ARABĪ. The Seven Days of the Heart: Prayers for the Nights and Days of the Week. Translated by Pablo Beneito and Stephen Hirtenstein. Oxford: Anqa Publishing, 2000, p. 57.

${ }^{14}$ A lo largo de este artículo, por tašbīh se entenderá 'cercanía' o 'inmanencia' divinas según la acepción de la escuela de Ibn 'Arabī y no 'antropomorfismo' según la acepción más habitual en la teología del kalām.

${ }^{15}$ Para la crítica de Ibn Taymiyya, véase Alexander D. KNYSH. Ibn 'Arabì in the Later Islamic Tradition: the Making of a Polemical Image in Medieval Islam. Albany: SUNY Press, 1999, pp. 87-112. 
tašbīh al-ittiḥādiyya o 'similitud de unificación', ${ }^{16}$ con el término hulül. La palabra hulül significa 'descender y habitar'. Como término teológico técnico se utiliza para designar el concepto de encarnación y, de forma general, la recepción de Dios en una forma creada o en el conjunto de la creación de modo que Dios desciende y habita en esa realidad creada produciéndose una unión substancial. En la teología islámica, hulūl es una forma de širk o asociación; es decir, una forma de asociación de otras realidades a Dios al considerarlas con carácter divino o como deidades. Širk es pues el término árabe para idolatría.

Ibn Taymiyya distingue, de hecho, cuatro tipos de hulül: (i) el ḥulül particular en el que la divinidad se encarna en un soporte humano como el agua en una tinaja; (ii) el hulül de unificación particular en el que la divinidad y la humanidad están mezcladas, como el agua y la leche, si bien sólo en un ser particular; (iii) el hulūl general según el cual Dios está en todos sitios; y (iv) el hulūl de unificación general según el cual Dios es la esencia concreta ('ayn) de los seres creados ( $k \bar{a}$ 'inăt) ${ }^{17}$ En cualquier caso, es importante subrayar que el concepto de hulül implica una dualidad con dos principios diferentes unidos: por una parte, Dios y, por otra, una realidad creada, o la creación en sí misma. Por lo tanto, el concepto de hulūl no equivale exactamente al de panteísmo, ya que en el hulūl se afirma la preexistencia de dos principios, mientras que en el panteísmo, al menos entendido de manera estricta, el cosmos, en su pluralidad, es Dios.

Si el tašbīh, en la acepción de Ibn 'Arabī de inmanencia divina, es percibido por algunas escuelas como una forma de idolatría, la afirmación absoluta del tanzīh o transcendencia e incomparabilidad divinas, junto a la negación absoluta del tašbīh, o similitud, conlleva el riesgo de ta 'ṭ̂ll. Ta 'țīl es el término en el que, según al-Aš arī, cae la mu 'tazila. ${ }^{18}$ La palabra ta 'țĭl significa 'desproveer', 'vaciar'; y de manera derivada 'arruinar', 'destruir'. Como término teológico, ta 'ṭ̂l significa considerar que Dios está desprovisto de todo atributo. ${ }^{19}$ Así pues, Dios sería concebido como una esencia absolutamente carente de cualquier atributo que lo asimilara a la creación. En última instancia, la afirmación absoluta del tanzīh y la negación del tašbīh implicaría un racionalismo agnóstico, según la traducción que da Corbin del

${ }^{16}$ Cf. IBN TAYMIYYA. Maŷmū 'at al-fatāwà. Ed. Anwar al-Bāz y 'Āmir al-Ŷazzār. alManșūra: Dār al-wafā' li-1-țibā'a, 1997, vol. II, p. 211.

${ }^{17}$ IBNं TAYMIYYA. Maŷmū' 'at al-fatāwà, vol. II, pp. 107-8.

${ }^{18}$ Cf. Abū l-Ḥasan AL-A Š 'ARĪ. al-Ibānā fì ușūl al-diyāna. Beirut: Dār Ibn Zaydūn, s.f., p. 42, donde al-Aš arī critica la mu tazila a propósito de los ŷahmiyya.

${ }^{19}$ El término complementario de ta ${ }^{t} \underline{\imath} \bar{l}$ es tat $\underline{t} \bar{i} t$ o $i \underline{t} b \bar{a} t$, por el que se afirma la predicabilidad de atributos positivos en Dios. Los términos ta 'țìl y mu atțil, i.e. aquel que profesa el ta ț $t \bar{l} l$, suelen utilizarse de manera despectiva para criticar posiciones racionalistas. Su uso despectivo es equivalente al uso despectivo de los términos tašbīh y mušabbih para criticar posiciones de los tradicionistas literalistas y en general cualquier posición que matice de alguna manera el tanzīh. Los tradicionistas ḥanbalīes se consideran a sí mismos como ahl al-ițbāt, el grupo de los que afirman el ițbāt, en lugar de ahl al-tašbìh, el grupo de los que afirman el tašbìh . 
término $t a{ }^{\prime} t \bar{l} l,{ }^{20}$ y llevaría a que Dios no fuera necesario para justificar el desarrollo del cosmos en el tiempo. Desde una perspectiva teológica ta țìli , el cosmos tendría su origen en Dios, en tanto que creador, pero al no haber ninguna similitud, es decir ningún atributo en común entre Dios y el cosmos, no cabría ninguna relación entre Dios y cosmos tras el momento de la creación, ni por tanto tampoco cabría influencia. ${ }^{21}$ Dios sería entonces una hipótesis prescindible sólo aceptable por un acto de fe. Así pues, la concepción de Dios como absolutamente distante e incomparable, hasta el punto de que quede desprovisto de atributos, desemboca o bien en el agnosticismo, o bien en el fideísmo.

\section{Ibn 'Arabī y la vía media entre la incomparabilidad y la similitud}

Para Ibn 'Arabī, como para el común de los teólogos musulmanes, Dios es absolutamente incomparable, absolutamente transcendente. Sin embargo, la incomparabilidad (tanzīh) de Dios no impide a la par Su similitud. ${ }^{22}$

Ibn 'Arabī concibe diversos grados en el despliegue de la existencia (marātib al$w u \hat{y} \bar{u} d$ ) desde el grado absolutamente transcendente de Dios -i.e. la Esencia de Dios

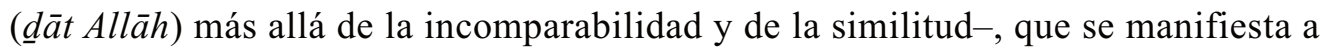
través de la efusión santísima (al-fayḍ al-aqdas) y la efusión santa (al-fayd al-muqaddas) en grados paulatinos de pluralización, hasta la manifestación (taŷallī) de Sus nombres en locus de manifestación (maẓhar, pl. mazāhir), que en sí no son existentes, dando lugar al universo manifestado. ${ }^{23}$ Ibn 'Arabī concibe el universo como manifestación (tâyallī) de los nombres de Dios (asmā' Allāh), como teofanía de Sus nombres, de modo que en su percepción y teorización del universo como teofanía de los nombres de Dios -i.e. de Sus atributos- radica la similitud entre Dios y el cosmos.

\footnotetext{
${ }^{20}$ Henry CORBIN. En Islam iranien I. París: Gallimard, 1971, p. 21.

${ }^{21} \mathrm{Ibn}$ 'Arabī expresa esta idea en una alusión a la continua existenciación de las formas en la naturaleza mediante la exhalación del Omni-Misercordioso (nafas al-Rahmānn). Para Ibn 'Arabī, si el acto creador divino no se renovara continuamente en el tiempo (jalq $\hat{y}$ adì $d$ ), ello supondría ta 'ṭ̂l. IBN 'ARABĪ. al-Futūḥāt al-makiyya. El Cairo: Dār al-kutub al-'arabiyya alkubrà, 1911, vol. II, p. 427.

${ }^{22}$ Ibn 'Arabī dedica el capítulo de Noé de su Fuṣuṣ al-hikam a la articulación del tašbīh y el tanzīh. Para este capítulo, cf. IBN 'ARABĪ. Fușūs al-hikam. Ed. 'Afīfì. Beirut: Dār al-kitāb al'arabī, s.f. (reimpreso a partir de la ed. El Cairo, 1946), pp. 68-74. Para un estudio de este capítulo, véase Toshihiko IZUTSU. Sufism and Taoism. A Comparative Study of Key Philosophical Concepts. Berkley: University of California Press, 1983, pp. 48-67.

${ }^{23}$ Para la ontología de Ibn 'Arab̄̄, vid. IBN 'ARABĪ. La production des cercles. Kitāb inshā al-dawā ir al-ilāhiyya. Intr. y trad. por Paul Fenton y Maurice Gloton, París: L'Eclat, 1996. Para una descripción básica de los niveles de la existencia (marātib al-wuŷūd) en Ibn 'Arabī, vid. pp. XXVI-XXIX.
} 
Sin embargo, es importante subrayar que Ibn 'Arabī concibe la Ipseidad (huwiyya) divina como absoluta y radicalmente transcendente.

Según Ibn 'Arabī, la percepción de la incomparabilidad divina tiene su base en la facultad racional. La razón señala lo que Dios no es dando lugar a un conocimiento negativo de Dios. La razón sabe lo que Dios no es, y al final duda si es. En cambio, la percepción de la similitud divina tiene su base en el conocimiento positivo por develación (kašf), inspiración (ilhām) o revelación profética (waḥ̄) mediante la facultad imaginativa $(j a y \bar{a} l) .{ }^{24}$

Para Ibn 'Arabī, tanto la afirmación exclusiva de la incomparabilidad (tanzīh) en detrimento de la similitud (tašbīh) como la afirmación exclusiva de la similitud en detrimento de la incomparabilidad comportan una aproximación incompleta y deficiente para captar la relación entre Dios y el universo. 'Abd al-Raḥmān al-Ŷāmī, un comentarista de Ibn 'Arabī, señala que ambas aproximaciones excluyentes son limitaciones de Dios. ${ }^{25}$ Para Ibn 'Arabī, la consecución del conocimiento sólo es posible mediante la conjunción de ambas aproximaciones: la incomparabilidad (tanzīh) y la similitud (tašbīh). Unos versos de Ibn 'Arabī resumen su postura: ${ }^{26}$

Si hablas desde la perspectiva de la incomparabilidad (tanzīh), limitas [a Dios] y si hablas desde la perspectiva de la similitud (tašbihh), [Lo] defines.

Si hablas desde ambas perspectivas, has alcanzado la meta ${ }^{27}$

y eres imām y señor en los conocimientos sapienciales (ma'ārif).

El término más utilizado en el texto que acompaña estos versos para señalar las consecuencias de renunciar a la similitud es taqyīd, que significa limitar o restringir algo, de modo que afirmar el aspecto de transcendencia sin inmanencia supone limitar o reducir a Dios. Para Ibn 'Arabī, la afirmación exclusiva de la incomparabilidad en detrimento de la similitud comporta idolatría oculta (širk jafî).$^{28} \mathrm{El}$ širk, o idolatría,


negar u oponerse a la existencia de Dios, lo que comporta quedar fuera de la fe (ìmān); mientras que el širk oculto significa negar la unidad (tawhīd) de Dios - expresada en la profesión de fe (šahāda) que afirma que "no hay dios sino Dios" ${ }^{29}$ - y que

${ }^{24} \mathrm{Cf}$. William C. CHITTICK. The Sufi Path of Knowledge: Ibn al- 'Arabī's Metaphysics of Imagination, p. 74.

${ }^{25}$ Véase el comentario de Ŷāmī del Naqš al-fusūṣs, resumen del Fuṣūs al-hikam de Ibn 'Arabī, donde se considera ambas perspectivas como limitación, si bien Ibn 'Arabī en general habla de limitación y definición. Cf. 'Abd al-Raḥmān al-ŶĀMİ. Naqd al-nușụ̄s fi šarḥ naqǔ al-fușūṣ. Beirut: Dār al-kutub al-'ilmiyya, 2005, p. 90.

${ }^{26}$ IBN 'ARABĪ. Fușūs al-hikam, p. 70.

${ }^{27}$ También puede traducirse como 'estás en el camino adecuado'.

${ }^{28}$ IBN 'ARABĪ. al-Futūhāt al-makiyya, vol. III, p. 375.

${ }^{29}$ IBN 'ARABĪ. al-Futūhạăt al-makiyya, vol. I, p. 400. 
Ibn 'Arabī parece entender a la vez de manera teológica - i.e. Dios es uno - y ontológica - i.e. sólo hay Dios en la existencia ${ }^{30}$-. A diferencia del širk manifiesto, el širk oculto es una forma inconsciente de širk y no comporta quedar fuera del $\bar{i} m \bar{a} n .{ }^{31} \mathrm{Ibn}$ 'Arabī, señala que el širk oculto consiste en confiar en las causas (asbāb) al margen de Dios, ${ }^{32}$ con lo que la afirmación exclusiva de la incomparabilidad en detrimento de la similitud - i.e. el širk oculto - consiste en otorgar una realidad separada a las causas al margen de Dios, lo que implica limitar (taqyìd) a Dios.

Ibn 'Arabī califica de ignorante o maleducado (șạhib sū' adab) a quien defiende la afirmación exclusiva de la incomparabilidad divina, lo que implica la limitación de Dios. Al comienzo del capítulo dedicado a Noé en su Fuṣuṣ al-hikam, ${ }^{33} \mathrm{Ibn}$ 'Arabī comenta: "Sabe, que Dios te ayude con un espíritu procedente de Él, que, para la gente de las realidades ( $a h l$ al-haq $\bar{a}^{\prime} i q$ ), la incomparabilidad (tanzīh) en lo que atañe a Dios es la fuente de la definición (taḩdìd) y la limitación (taqyīd), de modo que quien únicamente afirma la incomparabilidad es o bien un ignorante o bien un maleducado".

La mala educación se debe, según afirma Ibn 'Arabī un poco más adelante, al hecho de desestimar las afirmaciones de carácter tašbīhī en el Corán y el hadīt. Para Ibn 'Arabī, la idea que pretende vehicular el término 'similitud' (tašbīh), en tanto que inmanencia o cercanía divinas, en contraste con la distancia, incomparabilidad o transcendencia divinas (tanzīh), es de hecho coránica. Si aleyas como "Él es Dios (Allāh), cual no hay dios sino Él" (Corán 59:23), "Sea glorificado tu Señor, Señor de

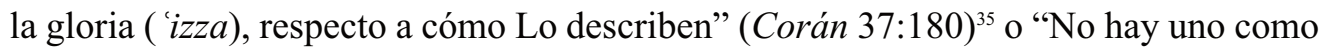
Él” (Corán 112:4), ${ }^{36}$ así como nombres como 'el Altísimo' (al- 'Alī), ${ }^{37}$ 'el Independiente' (al-Ṣamad) ${ }^{38}$ o simplemente el pronombre de tercera persona, Él (Huwa), ${ }^{39}$ aluden a la absoluta transcendencia divina, aleyas como: "A Dios pertenece el oriente y el occidente. A donde quiera que os volváis, allí hallaréis la Faz de Dios"

\footnotetext{
${ }^{30}$ Por ejemplo, "en la existencia no hay nada excepto Dios, Sus nombres y Sus acciones". IBN 'ARABĪ. al-Futūhāt al-makiyya, vol. III, p. 68.

${ }^{31}$ IBN 'ARABĪ. al-Futūhàt al-makiyya, vol. IV, p. 465.

${ }^{32}$ IBN 'ARABĪ. al-Futūhāt al-makiyya, vol. IV, pp. 457-8.

${ }^{33}$ IBN 'ARABĪ. Fuṣuṣ all-h̆ikam, p. 68.

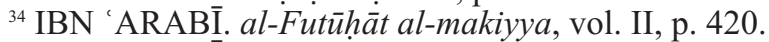

${ }^{35}$ IBN 'ARABĪ. al-Futūhāt al-makiyya, vol. I, p. 204.

${ }^{36}$ IBN 'ARABĪ. al-Futūhāt al-makiyya, vol. IV, p. 349.

${ }^{37}$ IBN 'ARABĪ. al-Futūhàt al-makiyya, vol. I, p. 691.

${ }^{38}$ IBN 'ARABĪ. al-Futūhāt al-makiyya, vol. II, p. 580.

${ }^{39}$ En la gramática árabe, el pronombre de tercera persona es designado como 'el ausente' $(g \bar{a} ' i b)$. De modo equivalente, Ibn 'Arabī define huwa como el oculto esencial (al-gayb al$\underline{d} \bar{a} t \bar{\imath})$, el ausente, que no puede ser contemplado. Cf. IBN 'ARABĪ. Kitāb iștilāh al-șūfiyya, p. 540, en IBN 'ARABĪ. Rasā'il Ibn 'Arabì. Ed. M.M. Gurāb. Beirut: Dar Sader, 1997, pp. 52941; e IBN 'ARABĪ. al-Futūhāt al-makiyya, vol. II, p. 128. En torno al pronombre huwa, véase asimismo IBN 'ARABĪ. Kitāb al-yā' en IBN 'ARABĪ. Rasā'il Ibn 'Arabī, pp. 137-47.

${ }^{40}$ IBN 'ARABĪ. al-Futūhāt al-makiyya, vol. II, p. 3; y vol. IV, p. 213.
} 
(Corán 2:115) ${ }^{40} \mathrm{o}$ "Nos estamos más cerca de él que su vena yugular" (Corán 50:16), ${ }^{41}$ y nombres como 'el Exterior' (al-Z̄āhir) ${ }^{42}$ parecen aludir al aspecto de inmanencia o proximidad divinas.$^{43}$ Del mismo modo, Ibn 'Arabī señala aleyas que sintetizan los aspectos de transcendencia e inmanencia divinas, de tanzīh y tašbīh, como por ejemplo "No hay nada como Él y Él es El-que-escucha, El-que-ve" (Corán 6:103) de modo que "No hay nada como Él” refleja el aspecto de tanzīh y "Él es El-que-escucha, Elque-ve" refleja el aspecto de tašbīh. ${ }^{44}$

Si la afirmación exclusiva de la incomparabilidad comporta la limitación de Dios, la similitud comporta la acción de definir (taḩdīd) a Dios. ${ }^{45}$ Ibn 'Arabī parece utilizar el concepto de definición (hadd) tanto desde la perspectiva ontológica, con lo que 'definir' equivaldría a delimitar una realidad dada, como desde la perspectiva epistemológica más propia del término 'definir', si bien la perspectiva ontológica parece tener preeminencia y la epistemológica derivarse de ella. El término hadd puede traducirse indistintamente como 'definición' y como 'límite' e Ibn 'Arabī parece jugar con esta ambigüedad. Para Ibn 'Arabī, el hecho de caracterizar la similitud como definición o limitación no es una crítica en sí misma de la similitud divina, sino más bien una descripción de la naturaleza de los seres creados. La definición (ḥadd) deviene problemática cuando se afirma la similitud de manera exclusiva en perjuicio de la incomparabilidad. Para Ibn 'Arabī, la definición ( hadd) de algo comporta la afirmación de un aspecto interior y un aspecto exterior: un espíritu (rūh) y una forma

${ }^{41}$ IBN 'ARABĪ. al-Futūhāt al-makiyya, vol. I, p. 420; y vol. IV, p. 358.

${ }^{42}$ Cf. Corán 57:3: “Él es el Primero y el Último, el Exterior y el Interior". Para la vinculación del nombre al-Zāhir al aspecto de tašbīh, cf. IBN 'ARABĪ. Fuṣūs al-ḥikam, p. 68. Para una anécdota en contexto sufí en la que la comprensión del nombre 'el Exterior' (al-Ẓāhir) da pie a la realización de la contemplación de la inmanencia divina en el cosmos, cf. al- 'Arabī alDARQĀWĪ. Maŷmū 'at rasā'ìl magribiyya. Abu Dabi: al-Maŷma' al-taqāfī, 1999, p. 89.

${ }^{43} \mathrm{Ibn}$ 'Arabī clasifica los nombres de Dios de diversas formas. En una de ellas, clasifica los nombres en nombres que Dios no ha dado a conocer y guarda para Sí, y nombres que ha dado a conocer. Estos últimos, a su vez, se dividen en nombres propios, como Allāh, y nombres calificativos $\left(n u^{\prime}\right.$ 'ut $)$, que a su vez se dividen en nombres de incomparabilidad (asma $\bar{a}^{\prime}$ al-tanzīh) y nombres de actos (asma ' al-af' $\bar{a} l$ ) o de similitud (asma' 'al-tašbīh). Véase IBN 'ARABİ. $E l$ secreto de los nombres de Dios. Ed. Pablo Beneito. Murcia: Editora regional de Murcia, 1996, pp. 17-8; y al-Futūhât al-makiyya, vol. II, p. 58; y vol. III, p. 106. Véase también, William C. CHITTICK. The Sufi path of Knowledge: Ibn al- 'Arabì's metaphysics of imagination. Albany: SUNY Press, 1989, p. 58.

${ }^{44}$ De hecho, Ibn 'Arabī señala que esta aleya puede tener una interpretación inversa. La comparación 'como' (ka-mitli) en "No hay nada como Él” es redundante - es decir, es una doble comparación 'como como' (ka-mițli) -, por lo que podría traducirse como "No hay nada como el-como-Él", de modo que, según esta interpretación, la incomparabilidad - "no hay nada como" - aludiría a la similitud de Dios - "el-como-Él" - y no al propio Dios. Del mismo modo, "Él es El-que-escucha, El-que-ve" podría interpretarse como que Dios es el sujeto de toda visión y audición, de modo que los seres quedarían desposeídos de las mismas. Cf. IBN 'ARABĪ. Fuṣūs al-hikam, p. 70.

${ }^{45}$ Para este desarrollo, véase IBN 'ARABĪ. Fușūṣ al-ḥikam, pp. 68-9. 
(șüra). La forma de algo, tomada de manera exclusiva, no capta su esencia pues, por ejemplo, la forma de un ser humano hecho en la madera no es propiamente un ser humano si carece de espíritu. Lo que le concede ser un ser humano a un ser humano es el espíritu, la dimensión interior. La realidad interior es lo definido (mahdūd), mientras que la forma (sūra) es el elemento que propiamente define o limita. Se puede establecer aquí un cierto paralelismo con el concepto aristotélico de definición entendida como género y diferencia específica, si bien en el caso de Ibn 'Arabī, la dimensión interior no es un universal, sino una realidad concreta individual, que en última instancia Ibn 'Arabī identifica con Dios o la existencia (wuŷūd) ${ }^{46}$ Dios es el definido (maḥdūd) en toda definición ( hadd), el limitado (mahdūd) en toda limitación (hadd). Ibn 'Arabī señala que, para conocer la definición de Dios (ḥuṣūl ḥadd al-Haqq), es necesario conocer las definiciones de todas y cada una de las formas, lo que considera imposible, puesto que las formas no pueden ser abarcadas (yuhạtu bi-hā) en su totalidad, de modo que el conocimiento de Dios es imposible. Así pues, la vía de la similitud (tašbīh) en exclusiva no permite un conocimiento cabal de Dios, pues es imposible abarcar las formas, lo que supone, al igual que la vía de la incomparabilidad (tanzīh), cuando es considerada de manera exclusiva, una limitación (taqyīd) de Dios. Para sortear ambas limitaciones y llegar a ser un "imām y señor en los conocimientos sapienciales (ma 'ārif)", es necesario adoptar ambas perspectivas a la vez de manera sintética ( alà $l$-îymāl) y no analítica ('alà l-tafșìl). La reunión (maŷma) de ambas perspectivas de manera analítica no es posible, señala Ibn 'Arabī, pues no es posible abarcar el conocimiento en detalle o por separado (tafșill) de las formas en el universo, las cuales, en suma, constituyen la similitud (tašbīh) divina. La reunión de ambas perspectivas sí es posible, en cambio, de manera sintética. Ibn 'Arabī se apoya en el famoso dicho atribuido al Profeta, si bien no recogido en las colecciones canónicas: "quien se conoce a sí mismo, conoce a su Señor", ${ }^{47}$ para describir en qué modo ambas perspectivas - las perspectivas propias de la incomparabilidad y de la similitud - pueden ser reunidas de manera sintética. El conocimiento de sí mismo - que en el dicho se expresa en "quien se conoce a sí mismo" - es el conocimiento de la forma que define o delimita a Dios, de Su similitud, y este conocimiento de sí mismo permite el conocimiento de Dios en Su incomparabilidad que se expresa en la segunda parte del dicho en "conoce a su Señor". Dios, afirma Ibn 'Arabī, es la realidad interior del universo y el universo la forma de Dios. La posición de Dios respecto al universo es la misma que la del espíritu respecto al cuerpo en el ser

\footnotetext{
${ }^{46}$ Para que esta simetría no lleve a confusión, tal como veremos, los filósofos post-avicenianos de la escuela de la hikma muta áliya han subrayado que la existencia (wuŷūd) no es un universal y sí una realidad concreta ('ayn $\vec{\imath})$ individual ( $\check{s} a j s \underline{\imath})$.

${ }^{47}$ Este dicho se atribuye, de hecho, al sufí Yahyà b. Mu'ād al-Rāzī (m. 871). Cf. Louis MASSIGNON. Essai sur les origines du lexique technique de la mystique musulmane. París: Paul Geuthner, 1922, p. 239.
} 
humano, en la forma humana. El conocimiento de Dios es posible en la medida del conocimiento que la propia forma tiene de sí misma, pero no es posible el conocimiento completo de Dios, pues no es posible abarcar y conocer todas las formas del universo.

En resumen, Ibn 'Arabī afirma una teología negativa radical - pues concibe la Ipseidad divina como absolutamente transcendente -, que, para que sea absolutamente negativa, requiere de una teología positiva en la que el universo es interpretado como teofanía, pues, si fuera de otro modo, la negación teológica constituiría una limitación de Dios. Es decir, una teología negativa radical exige la teología positiva. O dicho de otra forma, Dios transciende Su transcendencia mediante Su inmanencia. Y es el conocimiento que la teofanía tiene de sí misma, en tanto que inmanencia divina, lo que le posibilita el conocimiento de Dios, en Su transcendencia, en la medida de sí misma.

\section{Existencia y quiddidad}

La articulación de la transcendencia y la inmanencia divinas, de la incomparabilidad (tanzīh) y la similitud (tašbīh) divinas, tal como la plantea Ibn 'Arabī, supone un problema no sólo teológico, sino también filosófico. Ibn 'Arabī ejerció un honda influencia en el Mundo islámico. Su metafísica, que con el tiempo convino en llamarse wahdat al-wuŷūd, fue meditada a lo largo del Mundo islámico, no sólo por teólogos y espirituales, sino también por filósofos pertenecientes a las escuelas de la filosofía islámica tardía.

La solución racional al problema en torno a la articulación de la transcendencia e inmanencia divinas y, en definitiva, la discusión en torno a la wah̆dat al-wuŷùd está vinculada a la discusión en torno al primado de la existencia (wuŷūd, esse $)^{48} \mathrm{o}$ de la quiddidad (māhiyya, essentia) en la filosofía islámica tardía (hikma), i.e. la filosofía islámica posterior a Avicena y Averroes. Con el objeto de explicitar este vínculo, me propongo describir la discusión en torno al primado de la quiddidad o de la existencia, así como la articulación de la existencia y la quiddidad en el pensamiento de Mullā Șadrā, pues proporciona una justificación racional de la articulación de la transcendencia e inmanencia divinas.

La quiddidad (māhiyya), o esencia, de una cosa es la respuesta a la pregunta ¿qué es? (mā hiya); mientras que la existencia (wuŷu $d)$ de una cosa es la respuesta a la

\footnotetext{
${ }^{48}$ Las traducciones más comunes para el término wuŷūd son 'existencia', 'ser' y a veces, 'acto de ser', si bien la traducción literal sería 'el acto de ser encontrado' al tratarse de un deverbal de la forma pasiva del verbo encontrar (waŷada). El término wuŷūd conjuga, entonces, el aspecto de ser o existencia y el aspecto de conocimiento. Tanto la traducción por 'ser' como por 'existencia' tienen inconvenientes. En persa, a veces se distingue entre wuŷū con el significado de 'existencia' y hasteh con el significado de 'ser'.
} 
pregunta ¿acaso es? Una quiddidad se caracteriza por el hecho de poseer una definición. La definición es una frase que enuncia la esencia - i.e. la quiddidad - de una cosa ${ }^{49}$ Por lo tanto, toda quiddidad, y con ella todo ser, es por definición delimitada, ya que se diferencia de otras quiddidades. Cabe imaginar la existencia de quiddidades que sean ilimitadas en un aspecto, como por ejemplo un espacio infinitamente extenso. Sin embargo, una quiddidad, aunque pudiera ser ilimitada en un aspecto, no es el infinito, ya que está delimitada por lo que la distingue de otra quiddidad. La quiddidad de la quiddidad, es decir la definición ( $\operatorname{tahdìd}$ ) de la quiddidad, es la

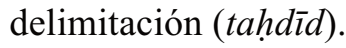

En cualquier caso, existencia ( $w u \hat{y} \bar{u} d$ ) y quiddidad (māhiyya) son principios independientes, ya que puede haber quiddidades que carezcan de existencia. Es decir, la existencia de un ente es adicional a su quiddidad (ziyādat al-wuŷūd 'alà l-māhiyya).

El problema en torno al primado de la quiddidad (așālat al-māhiyya) o de la existencia (așālat al-wuŷūd) busca determinar qué principio es el fundamentalmente real: o bien (i) la existencia es fundamentalmente real (așālat al-wuŷūd) y, por tanto, las quiddidades de los seres son percepciones mentales sin que tengan existencia en sí - en tanto que quiddidades - fuera de la mente; o bien (ii) las quiddidades de los seres son las fundamentalmente reales (așālat al-māhiyya) y, por tanto, la existencia se predica de las quiddidades como un universal abstraído por la mente sin que tenga realidad en sí. A lo largo de la filosofía islámica tardía, ha habido tanto partidarios del primado de la existencia como del primado de la quiddidad; es decir partidarios de que la existencia es lo fundamentalmente real, como de que la quiddidad es lo fundamentalmente real. Entre los primeros, quizá los más conocidos son Ibn 'Arabī y Mullā Șadrā, mientras que entre los segundos puede citarse a Suhrawardī (m. 587/1191) ${ }^{50}$ y Mīr Dāmād (m. 1040/1631), maestro de Mullā Șadrā. ${ }^{51}$

\footnotetext{
${ }^{49}$ ARISTÓTELES. Tópicos. I.5.

${ }^{50}$ Algunos autores, a partir de la interpretación de Mullā Șadrā, no ven en la posición de Suhrawardī una defensa del primado de la quiddidad. Mullā Șadrā considera que el concepto de luz en Suhrawardī equivale a su concepto de wuŷūd con lo que la posición de Suhrawardī quizá cabría calificarla como una defensa del primado de la luz. Si se acepta la interpretación de Mullā Șadrā, la diferencia entre Suhraward̄̄ y Șadrā sería entonces de carácter terminológico. Cf. Toshihiko IZUTSU. The Fundamental Structure of Sabzawārī's Metaphysics. Teherán: Tehran University Publications, 1990, p. 6; y Sajjad H. RIZVI. "An Islamic Subversion of the Existence-Essence Distinction? Suhrawardi's Visionary Hierarchy of Lights". Asian Philosophy: An International Journal of the Philosophical Traditions of the East, IX, 3, 2009, pp. 219-22.

${ }_{51}$ A lo largo de la filosofía islámica tardía ha existido alguna posición adicional como la de Šayj Aḥmad al-Aḥsā'̄ (m. 1241/1826) que sostuvo que el primado correspondía a ambos principios a la vez - i.e. la existencia y la quiddidad - o Ŷalāl al-Dīn al-Dawwānī (m. 908/1502) que sostuvo que, en lo que respecta al ser necesario, el primado correspondía a la existencia y, en lo que respecta a los seres contingentes, a la quiddidad.
} 
Suhrawardī considera que la existencia es una noción mental sin realidad. ${ }^{52}$ Así pues, para su escuela, los seres (mawŷūdāt) son idénticos a sus quiddidades sin existencia advenida. Para Suhrawardī, si la existencia fuera el principio fundamentalmente real, debería tener a su vez otra existencia que la hiciera ser existente, y ésta, a su vez, una nueva existencia que la hiciera ser existente, etc., con lo que se caería en un regreso infinito, lo que es imposible. ${ }^{53} \mathrm{Al}$ mismo tiempo, señala la contradicción que se deriva de considerar la existencia como un accidente de la quiddidad, pues al ser un accidente de la quiddidad, ésta debe existir antes de la existencia, para que la existencia pueda predicarse como accidente de la quiddidad, con lo que la existencia de la quididdad es anterior a la existencia; es decir la existencia es anterior a sí misma, con lo que se produciría un círculo vicioso. ${ }^{54}$

Mullā Șadrā ${ }^{55}$ y su escuela, conocida como hikma muta āliya o filosofía transcendente, de la que forman parte Sabzawārī (m. 1289/1873) ${ }^{56}$ y Țabāțabā' 1 (m. 1402/1981), afirman el primado de la existencia (așālat al-wuŷūd); es decir, que la existencia es lo fundamentalmente real, mientras que la quiddidad, en tanto que quiddidad, sólo tiene realidad mental. Para la hikma muta āliya, los seres son una conjunción de quiddidad y existencia de modo que, si bien, desde el punto de vista epistemológico, el intelecto abstrae la existencia de la quiddidad como un accidente, desde el punto de vista ontológico, ocurre al revés: la quiddidad es, de hecho, un accidente de la existencia. ${ }^{58}$ Mullā Ṣadrā

${ }^{52}$ En palabras de Suhrawardī: "Por lo tanto, todos los atributos pueden dividirse en dos clases: [En primer lugar,] el atributo concreto (sifa 'ayniyya) que tiene una forma en el intelecto - como negro, blanco o movimiento -; y [en segundo lugar,] el atributo cuya existencia concreta no está sino en la mente, y no tiene existencia fuera de la mente [...] - como por ejemplo contingencia, sustancialidad, color-idad y existencia (wuŷūd)". Cf. SUHRAWARDI. The philosophy of Illumination. A New Critical Edition of the Text of Hikmat al-ishrāq with English Translation, Notes, Commentary and Introduction by John Walbridge and Hossein Ziai. Provo, Utah: Brigham Young University Press, 1999, p. 50.

${ }_{53}$ SUHRAWARDİ. The Philosophy of Illumination, pp. 45 y ss.

${ }^{54}$ SUHRAWARDI. The Philosophy of Illumination, p. 46.

${ }^{55}$ En torno a Mullā Șadrā, en castellano contamos con los trabajos pioneros de Carlos Andrés Segovia entre los que cabe destacar, para el tema que nos atañe, Carlos A. SEGOVIA. "Univocismo y monadología en el pensamiento iraní postaviceniano. La prosecución filosófica del 'irfān de Ibn al- 'Arabī en la obra de Șadrā Šīrāzī'. Anales del seminario de Historia de la Filosofía, XVIII, 2001, pp. 79-108; y Șadr ad-Dīn Šìnāzì. La filosofía islámica y el problema del ser. Estudio y comentario del Kitāb al-mašā ir. Granada: Universidad, 2005.

${ }^{56}$ En torno a Sabzawārī, véase Hāŷŷyi Mullā Hādī SABZAWĀR̄̄. The Metaphysics of Sabzavārī. Translated from the Arabic by Mehdi Mohaghegh and Toshihiko Izutsu. Teherán: Tehran University Press, 1969; y Sajjad H. RIZVI. "Hikma muta' āliya in Qajar Iran: Locating the Life and Work of Mullā Hādī Sabzawārī (d. 1289/1873)". Iranian Studies, XLIV, 4, 2011, pp. 473-96.

${ }_{57}$ Para el pensamiento de Ṭabāțabā' 1 como hakìm muta 'allih, cf. Sayyid Muhammad Husayn ȚABĀṬABA' İ. Elements of Islamic Metaphysics. Bidāyat al-Hikma. Trad. Sayyid 'Alì Qūlī Qarā' $\mathbf{1}$. Londres: ICAS Press, 2003.

${ }_{58}$ Cf. IZUTSU. The Fundamental Structure of Sabzawārī's Metaphysics, pp. 101-18; y ȚABĀṬABA' '̄. Elements of Islamic Metaphysics, pp. 10-2. 
señala que la anterioridad (taqaddum) de la existencia respecto a la quiddidad no es la propia de la causa y lo causado, o del receptor respecto a lo recibido, sino la propia de lo que es por esencia ( $b i-l-\underline{d} \bar{a} t)$ respecto a lo que es por accidente (bi-l- 'arad ), o lo que es en realidad (bi-l-haqiq a) respecto a lo que es en sentido figurado o metafórico $(b i-l-m a \hat{y} \bar{a} z){ }^{59}$

Respecto al primero de los argumentos de Suhrawardī con los que pretende refutar la așālat al-wuŷūd basado en el regreso infinito, la escuela de Mullā Șadrā responde que la existencia no requiere de otra existencia para hacerla existente, pues ello supone considerar a la existencia como una quiddidad. La existencia es existente por sí misma y no "un" existente que requiera de existencia advenida en un regreso infinito. ${ }^{60}$

Respecto a la crítica de Suhrawardī a la interpretación aviceniana de la existencia como accidente de la quiddidad de modo que la quiddidad es existenciada al recibir el accidente 'existencia', Mullā Șadrā señala que Avicena, en sus Ta 'līqāt ${ }^{61}$ menciona que "la existencia de todos los accidentes en sí mismos es su existencia [i.e. la de los accidentes] en sus substrata (mawdī 'àt), excepto en el caso de un accidente: la existencia $(w u \hat{y} \bar{u} d)$. Esta diferencia se debe a que todos los accidentes, para ser existentes, necesitan de un substratum, mientras que la existencia no necesita de ninguna existencia para ser existente". ${ }^{62}$ Es decir, la existencia de los accidentes no es otra que la existencia del substrato del cual se predican, excepto en el caso de la existencia pues es existente en sí misma.

Los filósofos de la hikma muta áliya, en su defensa del primado de la existencia (așālat al-wuŷūd), distinguen dos existencias: la existencia real en sí (haquĩqat al$w u \hat{y} \bar{u} d$ ), y el concepto de existencia (mafh $\bar{u} m$ al-wuŷud) abstraído a partir de los seres

\footnotetext{
${ }^{59}$ Șadr al-Dīn al-Šìrāzī [Mullā ȘADRĀ]. Kitāb al-mašā ìr. Ed. Henry Corbin. Teherán: Institut français d'Iranologie, 1956, p. 24, §55.

${ }^{60} \mathrm{TAB} \overline{\mathrm{A}} \mathrm{T} \mathrm{AB} \overline{\mathrm{A}} \overline{\mathrm{I}}$. Elements of Islamic Metaphysics,, $\mathrm{p} .7$.

${ }^{61}$ Esta cita parece no encontrarse en la edición de Badawī de las Ta 'īqāt de Avicena probablemente por diferencias entre los manuscritos utilizados por Șadrā y Badawī. Mullā Șadrā parece citar una variante, quizá primero corrupta y luego interpolada, de IBN SĪNĀ. al-Ta 'ī̄qāt. Ed. \& introd. 'Abd al-Raḥmān Badawī. El Cairo: G.E.B.O., 1973; reimpr. Teherán, Maktab al- 'ālam alislāmī, 1985, pp. 176-7. En este texto, Avicena señala que la existencia, si bien se predica - i.e. es un predicado (mahmū $l$ ) -, no es un accidente, ni se halla en un substrato, ni es un género, ni una substancia (ŷwhar). El hecho de que la hikma muta'äliya, siguiendo a Avicena, no considere el wuŷūd como substancia diferencia a esta escuela de las tesis de Spinoza. Para la atenta lectura de Mullā Șadrā de las Ta 'līqāt, cf. Jules JANSSENS. "Mullā Șadrā's Use of Ibn Sīnā's Ta 'T̄qāt in the Asfär r". Journal of Islamic Studies, XIII, 1, 2002, pp. 1-13.

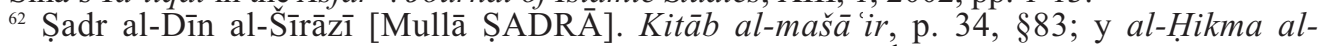
muta 'áliya fí l-asfār al- 'aqliyya al-arba'a. Ed. Muhammad Riḍā' al-Muẓaffar, 9 vols. Beirut: Dār iḥyà' al-turāt al- 'arabī, 1401/1981, vol. I, pp. 47-8. Mullā Șadrā, tras recordar esta cita, menciona su conversión de la defensa del primado de la quiddidad al primado de la existencia, por lo que cabe suponer que su lectura de las Ta 'i $\bar{l} q \bar{a} t$ haya sido instrumental en esta conversión. Cf. Kitāb al-mašā ir, p. 35, §85.
} 
existentes. ${ }^{63}$ Así pues, señalan que, si bien percibimos la existencia como un concepto universal mental abstraído de los existentes - una intención segunda -, y en ello coinciden con el concepto de existencia al que se refiere Suhrawardī, la existencia es, en primer lugar, el substrato de la realidad que se impone al ser lo más evidente. Si bien el concepto de existencia, en tanto que concepto mental universal, es posterior a la quiddidad, pues se predica de ella, la existencia, en tanto que realidad más evidente, absolutamente simple, infinita y carente de quiddidad, es previa a la quiddidad.

Ambas existencias - i.e. la existencia real en sí y el concepto de existencia - se dividen en dos cada una. Sabzawārī divide primero el concepto de existencia en (i) el concepto de existencia absoluta (wuŷūd muṭlaq) - i.e. el concepto de la existencia absolutamente simple y sin determinación que puede predicarse de toda cosa -; y (ii) el concepto de existencia determinada o limitada (wuŷūd muqayyad) - i.e. el concepto de la existencia particularizado y delimitado por una quiddidad -. A su vez, divide la existencia real en sí en (iii) la existencia singular general (fard 'àmm) ${ }^{64}-$ i.e. la existencia general que en su unidad contiene en sí todas las existencias particulares -; y (iv) la existencia singular particular (fard jāṣs) - i.e. la existencia propia de cada existente particular.$-^{65}$

Mullā Șadrā ofrece una distinción algo más detallada de la existencia real que nos servirá para introducir su comprensión de la existencia y la quiddidad en la que fundamenta su defensa del primado de la existencia. Mullā Șadrā, a partir de una inspiración recibida del Trono, divide la existencia real (haqūqat al-wuŷūd) en tres niveles (marātib al-wuŷūb) añadiendo a la distinción anterior en el seno de la existencia real el tertium quid. ${ }^{66}$

Mullā Șadrā señala que la existencia real se divide en:

(i) la existencia que no está en relación con algo que difiera de ella - es decir, la existencia absolutamente simple - y que no está limitada;

(ii) la existencia que se relaciona con algo diferente a ella - i.e. las existencias particulares que el intelecto analiza como quiddidades -; y

(iii) el tertium quid, la existencia desplegada (wuŷūd munbasiț) que contiene los templos (hayākil $)^{67}$ de las esencias concretas y las quiddidades.

Para Mullā Șadrā, la existencia pura - i.e. la existencia que no está en relación con algo que difiera de ella, pues no hay nada que difiera de ella - es una realidad absolu-

\footnotetext{
${ }^{63}$ Șadr al-Dīn al-Šìrāzī [Mullā ȘADRĀ]. Kitāb al-mašā ir, p. 11, §20.

${ }^{64} \dot{A}$ veces 'āmm puede traducirse por universal, si bien no debe entenderse en el sentido lógico del término. La existencia absoluta es individual concreta ( $\check{s} a j s ̣ \bar{l}$ 'aynī).

${ }^{65}$ IZUTSU. The Fundamental Structure of Sabzawārī's Metaphysics, pp. 123-5.

${ }^{66}$ Șadr al-Dīn al-Šìrāzī [Mullā ȘADRĀ]. Kitāb al-mašā irir, pp. 40-1, §97.

${ }^{67}$ El término templo (haykal) designa en la escuela de Suhrawardī a la quiddidad.
} 
tamente simple, concreta e individual, siendo también la realidad más evidente, por lo que no puede ser conocida mediante definición ni descripción. ${ }^{68} \mathrm{Al}$ ser absolutamente simple, no puede ser caracterizada por ninguno de los cinco universales - i.e. género, diferencia específica, especie, propiedad o accidente -, con lo que carece de definición. Al mismo tiempo, tampoco puede ser conocida mediante una descripción (rasm), pues es más evidente que la propia descripción.

El siguiente nivel existencial en la clasificación anterior, el de la existencia que se relaciona con lo que difiere de ella, es el grado de las existencias (wuŷūdāt) singulares particulares, que son sombras o limitaciones de la existencia pura.

Por último, el tertium quid, es el grado de la existencia desplegada (wuŷūd munbasit ) y constituye un nivel intermedio entre la existencia simple y las existencias particulares. La existencia desplegada es el primer nivel emanado (șādir awwal) a partir de la causa primera; es el principio de la existencia, de la vida y de la luz del universo. Se halla en toda cosa siendo esa cosa: intelecto en el intelecto, alma en el alma, cuerpo en el cuerpo, substancia en la substancia y accidente en el accidente. Es lo que los que conocen ('ārifün), i.e. los sufíes, denominan como el suspiro del OmniMisericordioso (nafas rahmmān $\bar{\imath}$ ), la verdad que crea (al-ḩaqq al-majlüq bi-hi al-jalq) o la realidad de las realidades (haqīqat al-haq $\left.\bar{a}^{\prime} i q\right) .{ }^{69}$

Por su parte, Mullā Șadrā describe la quiddidad (māhiyya) como un concepto universal que refleja en la mente la realidad existencial extramental. La quiddidad es el conjunto de atributos de una existencia abstraídos por el intelecto ( $a q l$ ). Para Mullā Şadrā, estos atributos sólo se dan unificados en su existencia concreta (anniyya) y ésta sólo puede ser conocida mediante conocimiento presencial ( $i l m$ ḥudūrū). Para Mullā Șadrā, la quiddidad en sí ni existe ni no existe, ni es general ni particular. ${ }^{70}$ Su realidad ontológica es intermedia entre la existencia y la no existencia. Si bien la quiddidad, en tanto que principio adicional a la existencia, no tiene existencia en sí, su existencia, en tanto que inteligible y como imitación (hikâaya) de la existencia extramental (wuŷūd jārîŷ̉), ${ }^{71}$ posee la existencia de una cualidad (kayfiyya) de la existencia mental (wuŷūd $\underline{\text { dihn }} \bar{\imath}){ }^{72}$ La realidad extramental de la quiddidad es la existencia individual concreta

\footnotetext{
68 "La realización (anniyya) [i.e. el esto, la hecceidad] de la existencia (wuŷūd) es la más manifiesta de las cosas $\left(a \bar{s} y \bar{a}^{\prime}\right)$ por lo que respecta a su presencia y develación (kašf); mientras que la quiddidad (māhiyya) de la [existencia] es la más oculta [de las cosas] por lo que respecta a su representación conceptual (tașawwur) y [a la posibilidad de] ser desentrañada (iktināh)". Șadr al-Dīn al-Šìāzī [Mullā ȘADRĀ]. Kitāb al-maša $َ$ ir , p. 6, §5.

${ }^{69}$ Mullā Șadrā sigue la división que da Ibn 'Arabī en su Inšā' al-dawā ir. Cf. IBN 'ARABĪ. La production des cercles, 16-8, e IBN'ARABĪ. al-Futūhāt al-makiyya, I, p. 119.

${ }_{70}$ Ṣadr al-Dīn Muḥammad al-Šīrāzī [Mullā ȘADRĀ̄]. al-Hikma al-muta 'àliya fì l-asfār al'aqliyya al-arba'a, vol. V, p. 2.

${ }^{71}$ Șadr al-Dīn al-Šîrāzì [Mullā ȘADRĀ]. Kitāb al-mašà ìr, pp. 40-1, §97.

${ }^{72}$ Cf. su tratado al-Masā'il al-qudsiyya en Șadr al-Dīn al-Sīrāzī [Mullā ȘADRĀ]. Seh resālah. Ed. Ŷalāl al-Dīn Āštiyānī. Qom: Markaz-i intišārāt-i daftar-i tablīgāt-i islā̄mī, 1983, p. 46.
} 
(anniyya) sin que haya en ella, de hecho, composición entre existencia y quiddidad. La quiddidad en la realidad extramental no difiere de la existencia concreta. ${ }^{73}$ Cuando el intelecto analiza una existencia concreta extramental distingue ya en la mente su existencia de su quiddidad, pero esta distinción no se da previamente en el mundo exterior donde sólo hay existencia. El intelecto, ya en el orden epistemológico, distingue la existencia y la quiddidad de modo que concibe la quiddidad como una realidad previa y eterna que recibe la existencia cuando ésta se predica de la quiddidad. Por ello, al ser la existencia un predicado de la quiddidad en el orden epistemológico, el intelecto concibe que la quiddidad es anterior a la existencia en el orden epistemológico, si bien para Mullā Șadrā, la existencia es lo fundamentalmente real al ser anterior a la quiddidad en el orden ontológico. ${ }^{74}$

Al carecer la quiddidad, en tanto que quiddidad, de existencia extramental, la quiddidad no puede ser el receptáculo de la existencia, pues ello implicaría que la quiddidad sería preexistente, lo que supondría un círculo vicioso.$^{75} \mathrm{Al}$ mismo tiempo, la quiddidad no puede ser el principio de individuación de las existencias, sino que éste debe proceder de una realidad existente individual que no puede ser otra que la propia existencia, pues si no fuera de este modo, ello implicaría que la quiddidad, en tanto que principio individual, fuera un existente individual anterior a su realización existencial individual, lo que supondría de nuevo un círculo vicioso. ${ }^{76}$ Ambos rasgos distinguen el concepto de quiddidad en Mullā Ṣadrā de las esencias inmutables ( $a$ yān $\underline{t} \underline{a}$ bita) de Ibn 'Arabī. ${ }^{77}$ Las a y yān țābita son esencias inmutables carentes de existencia propia ad extra que moran en el conocimiento divino y cuya existencia es una con la Esencia divina. Para Ibn 'Arabī, las a yān țābita son los seres tal como se muestran a Dios en Su conocimiento, independientemente de si les ha concedido la existencia o no; son los principios de individuación de los seres y sus causas formales. ${ }^{78}$

A partir de la caracterización anterior de la existencia y la quiddidad, Mullā Șadrā y su escuela refutan el primado de la quiddidad (așālat al-māhiyya). Si, según Mullā Șadrā y su escuela, la existencia no fuera lo fundamentalmente real y sí lo fuera, en cambio, la quiddidad, se seguirían algunas contradicciones. Por ejemplo, si la existencia fuera únicamente un concepto mental ( $\left.i^{\prime} t i b \bar{a} r \bar{l}\right)$ sin realidad extramental, no habría diferencia entre un ente en sí y el ente conocido, ya que no habría diferencia entre la

\footnotetext{
${ }^{73}$ Șadr al-Dīn al-Šìrāzī [Mullā ȘADRĀ]. Kitāb al-maša $i r$, pp. 22-3, §52.

${ }^{74}$ Șadr al-Dīn al-Šīāzi [Mullā ȘADRĀ]. Kitāb al-maša ‘ ir, pp. 30-1, §77.

${ }^{75}$ Șadr al-Dīn al-Šīināzị [Mullā Ș̣ARĀ] . Kitāb al-mašā ir ir, pp. 22-3, §51-2.

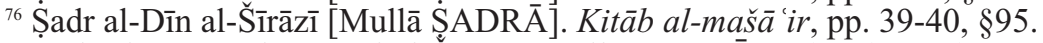

${ }_{77}$ Șadr al-Dīn Muḥammad al-S̄̉rāzī [Mullā ȘADRĀ]. al-Hikma al-muta àliya fì l-asfār al'aqliyya al-arba'a, vol. I, p. 49; y Kitāb al-mášà ir, pp. 35-6, §85-6.

${ }^{78}$ En torno a las a'yān tābita, cf. William C. CHITTICK. The Sufi Path of Knowledge: Ibn al'Arabi's Metaphysics of Imagination, pp. 83-8.
} 
realidad exterior objetiva y la mental. ${ }^{79}$ No habría tampoco posibilidad de que un ser saliera del estado de potencia, ya que las quiddidades estarían en igual relación respecto al acto y la potencia. Sólo podrían salir del estado de potencia en virtud de la existencia, pero dado que ésta sería un mero objeto mental, no podría haber seres actualizables; o lo que es lo mismo, no habría mundo físico, ni tampoco posibilidad de movimiento, cambio o transformación. ${ }^{80}$ Tampoco sería posible hablar de ningún tipo ni ningún grado de unidad en el seno de la realidad, pues la multiplicidad de las quiddidades determinaría múltiples realidades completamente independientes unas de las otras. ${ }^{81}$ Además, dado que la naturaleza de la quiddidad es la diferencia, no tendrían nada en común. ${ }^{82}$

En definitiva, según Mullā Șadrā y su escuela, para que podamos hablar de una realidad que albergue una multiplicidad de seres, es decir, para que podamos hablar de multiplicidad en la unidad, así como de cosmos, movimiento, cambio y transformación, causa y efecto, la existencia ( $w u \hat{y} \bar{u} d)$ debe ser lo fundamentalmente real, de modo que las quiddidades sean conceptos mentales derivados ( $\left.i{ }^{~} t i b \bar{a} r \vec{r}\right)$.

\section{La relación entre Dios y el cosmos desde la perspectiva del primado de la existencia}

Desde la perspectiva del primado de la existencia, la existencia pura se identifica con Dios ${ }^{83}$ ya que, al carecer de quiddidad, es infinita ${ }^{84} \mathrm{y}$, en su simplicidad, es todo atributo positivo de manera indiferenciada ${ }^{85}$ Dios es, pues, existencia pura, sin sombra de quiddidad, sin sombra de límite ni composición. Se dice que la quiddidad de

${ }^{79}$ SABZAWĀR̄i. The Metaphysics of Sabzavārī, p. 34.

${ }^{80}$ SABZAWĀRĪ. The Metaphysics of Sabzavārī, p. 36.

${ }^{81}$ SABZAWĀRI. The Metaphysics of Sabzavārī, pp. 37-8.

${ }^{82}$ Sabzawārī señala: "La quiddidad (māhiyya) es la fuente de la multiplicidad (kutra) y su naturaleza (fitra) es la diferencia (ijtilāf), pues las quiddidades (māhiyyāt) por sus propias esencias $(\underline{d} a w \bar{a} t)$ son diferentes y múltiples; y transmiten el polvo ( $g u b \bar{a} r)$ de la multiplicidad en la existencia (wuŷūd)". Cf. SABZAWĀRİ. The Metaphysics of Sabzavārī, p. 37. Para la edición árabe, cf. Hāŷŷyi Mullā Hādī SABZAWĀRĪ. Šarh gurār al-farā'id ma 'rūf be Šarh-e manżūmah-ye hekmat. Ed. Mehdi Mohaghegh \& Toshihiko Izutsu. Teherán: Silsilah-ye Dāniše İrānī, 1348, p. 45.

${ }^{83}$ Șadr al-Dīn al-S̄ìrāzī [Mullā ȘADRĀ]. Kitāa al-maša $i r$ ir, p. 52, §115.

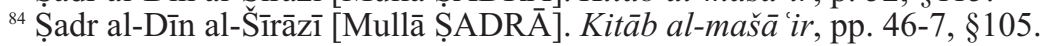

${ }^{85}$ Mullā Șadrā, en lo que respecta a la articulación de los atributos y la esencia divinos, adopta la posición de los rāsijūn fí l- 'ilm, aquellos cuya ciencia ha sido probada (cf. Corán 3:7), y que en otro lugar identifica con los 'urafā' o sufíes (cf. Kitāb al-mašā 'ir, p. 8, §12). Mullā Sadrā señala que los atributos de Dios son Su esencia (inna șifāta-Hu, ta 'ālā, 'aynu dâtiti-Hi) sin que, a diferencia de las tesis aš arīes, constituyan una pluralidad, ni, a diferencia de las tesis mu'tazilīes, deban negarse de la esencia divina, y sí, en cambio, se afirmen sus efectos. La existencia de los atributos en Dios es por accidente de modo equivalente a cómo la quiddidad se predica por accidente de una existencia contingente (mumkin al-wuŷūd), si bien en el caso de la Existencia necesaria ( $w \bar{a} \hat{y} i b$ al-wuŷūd) no puede hablarse de quiddidad. Șadr al-Dīn alŠìrāzì [Mullā ȘADRĀ] . Kitāb al-mašā 'ir, pp. 54-5, §117. 
Dios es la existencia sólo de manera metafórica, ${ }^{86}$ pues la existencia, en tanto que existencia, no puede ser delimitada ni, por tanto, definida. La única limitación propia de la existencia, y por tanto de Dios, es que no tiene limitación. La única definición de Dios es que carece de definición. ${ }^{87}$ Desde esta perspectiva, una vez se acepta la identificación de la existencia pura con Dios, preguntarse por la existencia de Dios equivale a cuestionarse la existencia de la existencia. ${ }^{88}$

¿Cuál es la relación, según el pensamiento de Mullā Șadrā y su escuela, entre la Existencia pura y necesaria, que en última instancia se identifica con Dios, y los seres contingentes (mawŷūāat) ${ }^{{ }^{89}}$ Mullā Șadrā señala que "la Existencia necesaria (waŷ̀̄b al-wuŷūd) [i.e. el Ser necesario] es la realidad simple (basīt al-haqīqa) en máximo grado y que cada realidad simple [en máximo grado] es todas las cosas. Así pues, la Existencia necesaria es todas las cosas y nada hay fuera de Ella". ${ }^{90}$

Para demostrar que nada queda fuera de la Existencia necesaria (wāŷyib al-wuŷūd) - i.e. el Ser necesario - Mullā Șadrā recurre a Su simplicidad. ${ }^{11}$ El argumento de la simplicidad del wuŷūd como prueba de la unicidad de la existencia (wah̆dat al$w u \hat{y} \bar{u} d$ ), es decir como prueba de que nada queda fuera de la existencia, consiste en señalar que la esencia $(\underline{d} \bar{a} t)$ de una quiddidad - y pone como ejemplo la quiddidad del ser humano y del caballo - está compuesta por lo que la define y por la negación $(s a l b)$ de las cosas concretas que difieren de ella - i.e. la esencia del ser humano está compuesta por lo que lo define como 'ser humano' y por lo que lo define como, por

${ }^{86}$ IBN SĪNĀ. al-Ta 'līqāt, p. 177. La existencia no posee quiddidad, sino anniyya, el hecho de ser, el esto de algo o su realización. Cf. Manuel ALONSO. "La al-anniyya y el al-wuŷūd de Avicena en el problema de esencia y existencia". Pensamiento: Revista de investigación e información filosófica, XV, 59, 1959, pp. 375-400.

${ }^{87}$ ȚABĀṬABA' '̄. Elements of Islamic Metaphysics, p. 9. En el grado opuesto está la materia, cuya única actualidad es que carece de actualidad.

${ }^{88}$ De manera resumida, la prueba de la existencia de Dios que aporta Mullā Șadrā es como sigue: si la existencia es una única realidad en grado de intensidad variable, siendo su máximo grado Dios, y existe un existente, Dios existe ya que es la existencia pura que hace existir el existente. Para la demostración de la existencia de Dios según Mullā Șadrā, cf. Fazlur RAHMAN. "The God-World Relationship in Mullā Șadrā" en George HOURANI (ed.). Essays on Islamic Philosophy and Science. Albany: SUNY Press, 1975, pp. 238-53, y en particular p. 248.

${ }^{89}$ Sobre este punto, véase Qāsem KĀKĀ'I. "Nazariy-e vaḥdat-e vojud va borhāni budan-e ān az didgāh Ebn- 'Arabi va Mollā-Șadrā”. Journal of Religious Thought. Faṣlnāme-ye andiše-ye dini dānešgāh-e Širāzi. I, Otoño, 1378/1999, pp. 55-77 (utilizo el sistema de transliteración de la Encyclopædia Iranica). Para la traducción inglesa, cf. Qāsim KĀK $\bar{A}$ ' $\bar{I}$. "The Theory of the Unity of Being and its Demonstrability in Mullā Șadrā and Ibn 'Arab̄̄” en Islam-West Philosophical Dialogue: The Articles Presented at the [First] World Congress on Mullā Sadrā (May 1999, Tehran). Volume 3. Mullā Sadrā and Comparative Studies [I]. Teherán: Sadra Islamic Philosophy Research Institute (SIPRIn), 2002, pp. 137-57.

${ }^{90}$ Șadr al-Dīn Muḥammad al-Šīrāzì [Mullā ȘADRĀ] . al-Hikma al-muta àliya fì l-asfār al'aqliyya al-arba'a, vol. II, p. 368.

${ }^{91}$ Para esta demostración, vid. Șadr al-Dīn Muḥammad al-Šīrāzī [Mullā ȘADRĀ]. al-Hikma al-muta 'àliya fì l-asfār al-'aqliyya al-arba'a, vol. II, pp. 368-72. 
ejemplo, 'no caballo', es decir como 'diferente de cualquier cosa diferente al ser humano'-. Pero como la Existencia necesaria es absolutamente simple, no puede estar compuesta por lo que ella es en concreto y por no ser las cosas concretas diferentes a Ella, de modo que, si la Existencia necesaria es absolutamente simple, nada concreto es diferente de Ella. Si se aduce, entonces, que la Existencia necesaria está compuesta de aquello que ella es - i.e. la existencia - y lo que no es - la carencia, la negación, en definitiva la inexistencia -, Mullā Șadrā responde que la negación de la inexistencia no supone una composición en su simplicidad, pues la negación de lo que es diferente de la existencia es la propia existencia. Por último, Mullā Șadrā cita varias aleyas coránicas corroborando que nada queda fuera de la Existencia necesaria: "No lanzaste cuando lanzaste, sino que Dios lanzó" (Corán 8:17); "y Él está con vosotros dondequiera que estéis" (Corán 57:4); y "Él es el Primero y el Último, el Exterior y el Interior; y Él es conocedor de todas las cosas." (Corán 57:3).92

Otro argumento se basa en la relación entre la causa ( 'illa) y lo causado ( $m a$ ' lül). Mullā Șadrā denomina 'instaurada' (mây 'ūl) a aquella existencia (wuŷūd) que no sea necesaria por sí misma y que, por tanto, recibe su existencia de una Existencia necesaria o instauradora $(\hat{y} \bar{a} i l)$. La existencia instaurada tiene siempre un grado de existencia menor que la instauradora. ${ }^{93}$ Mullā Șadrā señala que lo causado, es decir lo instaurado, no es una ipseidad (huwiyya) diferente de lo que lo causa, pues ni la causa ni lo causado son quiddidades, al ser la quiddidad un concepto mental ( $i$ 'tibara $\bar{l}$ ). La diferencia entre la causa y lo causado es por tanto mental y no real. La causa es causa en sí y lo causado es causado en sí. Es decir, lo causado no es una quiddidad independiente en sí misma que recibe el atributo de la existencia para llegar a la existencia, sino que la instauración de la causa que la instaura es su propia existencia. Lo causado es una existencia menos intensa que su causa, pero no separada ni diferente de ella; o dicho de otro modo, lo causado es una modalidad de la causa o su manifestación, pues la existencia de lo causado no es diferente de la de la causa. Por tanto, dado que Dios es la causa de todo, todo es la manifestación de Dios. ${ }^{94} \mathrm{O}$ dicho de otro modo, todo guarda una similitud (tašbīh) con Dios al ser Su manifestación.

\footnotetext{
${ }^{92}$ Sabzawārī rebate un argumento análogo basado en el carácter compuesto de la quiddidad por el hecho de recibir la existencia, frente al carácter simple de la existencia, aduciendo que esta prueba sólo puede proponerse si se acepta el primado de la existencia, con lo que implicaría una petición de principio, pues desde la asunción del primado de la quiddidad, las quiddidades son simples al ser su realidad la diferencia. La refutación de Sabzawārī no parece poder aplicarse al argumento anterior de Mullā Șadrā, pues en este caso la composición en la quiddidad no se debe a la adición de la existencia, sino a una composición inherente a la quiddidad en tanto que quiddidad. Para la refutación de Sabzawārī, cf. SABZAWĀRĪ. The Metaphysics of Sabzavārī, pp. 37-8.

${ }^{93}$ Șadr al-Dīn al-Šrīāzī [Mullā ȘADRĀ]. Kitāb al-mašā ir ir, p. 44, §106.

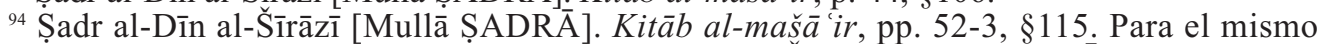
argumento, véase también Șadr al-Dīn Muhammad al-Šīrāzī [Mullā ȘADRĀ]. al-Hikma almuta 'āliya fì l-asfār al- 'aqlìyya al-arba'a, vol. II, pp. 299-300.
} 
Para Mullā Șadrā, "toda existencia diferente del Primero, la Verdad [i.e. Dios], sea ensalzado, es un destello radiante (lum 'a) entre Sus destellos radiantes, una faz entre Sus faces. Todos los existentes tienen un único principio (aṣl) que es el Realizador de las realidades, el Cosificador de las cosas, el Esenciador de las esencias. Él es la realidad y el resto Sus modalidades o estados $\left(\check{s} u{ }^{\prime} \bar{u} n\right)$. Él es la luz y el resto Su resplandor. Él es el principio y lo que hay más allá de Él son Sus exteriorizaciones (zuhūrāt) y Sus manifestaciones (tâyalliyāt)". ${ }^{5}$

Mullā Șadrā concibe la existencia como una única realidad graduada en diversos niveles de intensidad desde la existencia pura máximamente intensa asociada a Dios hasta el menor grado de intensidad existencial asociado a la materia. La existencia es una, pero la intensidad varía en una modulación descendente de modo que el grado inferior es manifestación del superior. La modulación o gradación de la intensidad de la existencia recibe el nombre de taškìk dada la ambigüedad (taškīk) que introduce en la existencia la gradación de su intensidad. ${ }^{96}$ Este término está tomado de la clasificación de las voces (alfāz) en unívocas (mutawāți'), polisémicas (muštarak) y ambiguas (mušakkak). El término mušakkak designa aquellas voces que no son estrictamente unívocas, pero cuyo significado está relacionado entre sí, como, por ejemplo, la predicación del Ser necesario y de los seres contingentes como existentes. ${ }^{97}$ En la acepción de Mullā Șadrā, dado que el wuŷūd es absolutamente simple, el wuŷūd se predica de manera unívoca de todos los seres, si bien de forma ambigua por lo que respecta a su grado de intensidad en cada uno de ellos, pues si la ambigüedad (taškīk) se diera en algún orden más allá de su intensidad, implicaría una composición en él.

Mullā Șadrā señala que las diferencias entre el concepto de wuŷūd en Ibn 'Arabī - i.e. una única realidad que se manifiesta en loci de manifestación (mażāhir) - y el concepto de wuŷūd en su pensamiento - i.e. una única realidad graduada en diversos grados de intensidad y debilidad, unidad y pluralidad, necesidad y contingencia, sustancialidad y accidentalidad, y autosuficiencia y dependencia -, son probablemente de carácter terminológico, debiéndose también a la diferente pericia de cada escuela en la expresión y en el detalle. ${ }^{98}$ Así pues, Mullā Șadrā parece sugerir que su pensamiento, la hikma muta àliya, es, al menos en parte, una reelaboración en términos filosóficos de los datos de la wahdat al-wuŷūd obtenidos por develación (kašf) y expresados inicialmente de forma parcialmente filosófica.

\footnotetext{
${ }^{95}$ Șadr al-Dīn al-Šīrāzī [Mullā ȘADRĀ] . Kitāb al-mašā ìr, pp. 52-3, §116.

${ }_{96}$ Ṕara un estudio del concepto del taškīk al-wuŷūd en Mullā Șadrā, vid. Sajjad H. RIZVI. Mullā Șadrā and Metaphysics: Modulation of Being. Abringdon: Routledge, 2009.

${ }^{97}$ IBN S̄iñ̄. 'Uyūn al-ḥikma. Ed. 'Abd al-Raḥmān Badawī. Beirut: Dār al-qalam, 1980, p. 3.

${ }^{98}$ Mullā ȘADRA Shīrāzì. On the Hermeneutics of the Light Verse of the Qur'ān. Translated, introduced and annotated by Latimah-Parvin Peerwani. Londres: ICAS Press, 2004, pp. 36-7. En esta referencia, Mullā Șadrā atribuye su propio pensamiento a la escuela išrāqī de Suhrawardī.
} 
En cualquier caso, pese a que Mullā Șadrā considera los seres causados como manifestaciones (taŷallì) de la existencia, la escuela de la hikma muta āliya no utiliza el término tašbīh, sino que habla de su sinónimo 'semejanza' (mušābaha) y de sinjiyya. Sinjiyya es la similitud entre la causa y el causado; es el elemento común (sinj) entre la causa ('illa), i.e. Dios, la Existencia necesaria (wâŷib al-wuŷūd), y lo causado ( $m a^{\prime} l \bar{u} l$ ), i.e. la existencia contingente (mumkin al-wuŷūd). ${ }^{99}$

Así pues, dado que la așālat al-wuŷūd es una elaboración racional influenciada por la wah̆dat al-wuŷūd, de modo que la hikma muta áliya comparte con la wah̆dat alwuŷūd la percepción del universo como un conjunto de teofanías, de manifestaciones del $w u \hat{y} \bar{u} d$, de existencia degradada, y afirma, por tanto, una postura que, en la terminología de la escuela de Ibn 'Arabī, sería considerada como similitud (tašbīh) divina sin que ello implique negar la incomparabilidad, la hikma muta āliya puede proporcionar una respuesta filosófica a las críticas teológicas que describen la wahdat al-wuŷūd o la aṣălat al-wuŷūd como formas de panteísmo o hulül. ¿Cuál es, por tanto, la posición de los filósofos (hukamā') de la escuela de la hikma muta äliya respecto a conceptos como panteísmo o hulül?

Para poder dar una respuesta a esta pregunta, al menos en lo que respecta al concepto de panteísmo, dado que este término es extraño a la tradición filosófica y teológica islámica, debemos conceptualizar el panteísmo en términos filosóficos y considerar la perspectiva desde la que puede tener sentido hablar del mismo en el contexto intelectual islámico.

En primer lugar, el panteísmo, desde la perspectiva del primado de la quiddidad, equivaldría a que un ser - Dios - fuera igual al resto de seres - el universo - o, dicho de otro modo, que la quiddidad de Dios, en tanto que quiddidad, fuera el resto de quiddidades, en tanto que quiddidades, lo que parece absurdo.

$\mathrm{Si}$, por tanto, el panteísmo no tiene sentido desde el primado de la quiddidad, cabe identificar a Dios con la existencia absoluta. Por lo tanto, sólo tiene sentido examinar el concepto de panteísmo desde una perspectiva en la que se identifique la existencia pura con Dios. Caben entonces dos posibilidades: o bien que el primado de la existencia (așālat al-wuŷūd), que en su realidad absoluta se identifica con Dios, sea una forma de panteísmo, o bien que la existencia sea idéntica a la quiddidad.

Para los filósofos de la hikma muta āliya, el panteísmo equivale a la postura en la que la existencia es idéntica a la quiddidad y no a la postura que afirma el primado de la existencia, la suya propia. El primado de la existencia no puede ser calificado de panteísmo, pues lo que nosotros entendemos por universo es, de hecho, el conjunto de quiddidades en nuestra mente de las existencias que conforman el universo, y no las propias existencias - manifestaciones de la existencia, o existencia degradada - que la mente percibe

${ }^{99}$ Cf. SABZAWĀRĪ. The Metaphysics of Sabzavārī̄, pp. 40-41 y Šarh gurār al-farā'id, p. 48. 
como realidades separadas e independientes. Mullā Șadrā defiende la wahdat al-wuŷūd en la última sección de su Risālat al-wuŷūd afirmando la transcendencia del wuŷūd. ${ }^{100}$ Para ello demuestra que la Existencia necesaria ( $w a \bar{y} \hat{i} i b$ al-wuŷud) y contingente (mumkin $a l-w u \hat{y} \bar{u} d$ ) no son dos tipos de existencias diferentes, sino una única existencia, pues si fueran dos tipos de existencias diferentes, ello implicaría una distinción en género y diferencia específica que justificara los tipos diferentes de existencia, lo que implicaría una composición en la existencia y que, por tanto, ésta no fuera necesaria. Mullā Șadrā afirma, además, la transcendencia de la existencia respecto a los seres contingentes que moran en la multiplicidad y la pluralidad al señalar: "La existencia (wuŷūd) es una realidad individual que transciende (haqiqqa šajṣiyya munazziha) la atribución accidental ( $a r \bar{u}(\underline{)})$ de la multiplicidad y la pluralidad y que no es subsistente ( $q \bar{a}$ 'im) sino por sí misma, mientras que las cosas subsisten por ella y se relacionan con ella mediante [(i)] una relación de unificación (nisba ittihāadiyya) [i.e. de identidad] como ocurre en el caso de la [Existencia] necesaria, sea ensalzada, o [(ii)] mediante una relación copulativa (nisba irtibātíyya) ${ }^{101}$ como ocurre en el caso de la [existencia] contingente." ${ }^{102}$ Así pues, Mullā Șadrā defiende la transcendencia del wuŷū relación con el wuŷūd es la propia de un accidente respecto a una substancia, lo que no quiere decir que conciba la existencia como una substancia. En consecuencia, si para los filósofos de la hikma muta āliya, la așālat al-wuŷūd afirma la transcendencia del wuŷūd, el panteísmo equivaldría a considerar que existencia y quiddidad son idénticos.

Esta postura - la identidad de la existencia y de la quiddidad - es explícitamente criticada por Sabzawārī, quien la atribuye a algunos de los proponentes de la wahdat alwuŷū ${ }^{103}$ Sabzawārī señala que, en el caso de que la existencia fuera idéntica a la quiddidad por predicación primaria esencial (haml awwalī $\underline{d} \bar{a} t \bar{l}),{ }^{104}$ se producirían una serie de contradicciones. Una de ellas es que las quiddidades, al ser idénticas a la existencia y ser la existencia una, se unificarían, no en su existencia, sino en tanto que quiddidades; es decir, serían una, no por lo que tienen en común - la existencia - sino por lo que las

${ }^{100}$ Șadr al-Dīn Muhammad al-Šīrāzī [Mullā ȘADRĀ]. Maŷmū'at rasā' il falsafiyya. Beirut: Dār ihyyā' al-turāt al- 'arab̄i, 1422/2001, pp. 473-84.

${ }^{101}$ La relación copulativa (nisba irtibătiyya) es la propia de la cópula entre una substancia y un accidente o un sujeto y un atributo. Cf. Șadr al-Dīn al-Šìrāzī [Mullā ȘADRĀ]. Kitāb almaša $i r$, pp. 32-3, §80.

${ }^{102}$ Șadr al-Dīn Muhammad al-Šīrāzī [Mullā ȘADRĀ]. Maŷmū 'at rasā' il falsafiyya, p. 482.

${ }_{103} \dot{\mathrm{S} A B Z A W} \overline{\mathrm{A}} \overline{\mathrm{I}}$. The Metaphysics of Sabzavārī, p. 44.

${ }^{104}$ En la predicación primaria esencial, el sujeto y el predicado son idénticos en su quiddidad y en su existencia como, por ejemplo, en 'Juan es un ser humano'. Esta predicación contrasta con la predicación común técnica ( $\left.\operatorname{haml} \check{s}^{\prime} \bar{a}^{\prime} i^{\prime} \sin \bar{a} \hat{\imath}\right)$ en la que la predicación sólo es igual en su realización existencial, pero no en su quiddidad, como, por ejemplo, en 'la casa es roja'. Esta es una prueba adicional del primado de la existencia, pues si el primado perteneciera a la quiddidad, no sería posible la predicación común técnica. Cf. Șadr al-Dīn al-Šīrāzī [Mullā ȘADRĀ]. Kitāa al-mašā ir ir, pp. 12-3, §23. 
hace diferentes entre ellas - la quiddidad -, lo que es absurdo. Sabzawārī señala también que la predicación de una quiddidad por otra debería ser por predicación primara esencial y ello llevaría a que sólo pudiera haber una única quiddidad.

En cuanto a las críticas teológicas de carácter neo-ḥanbalī que ven la waḥdat alwuŷùd como una forma de hulūl, la advertencia de Mullā Șadrā en su Kitāb al-mašā 'ir contra el peligro de caer en hulūl y unificación (ittiḥa $d$ ), que Ibn Taymiyya denomina ḥulū ittiḥ̂ad̄, nos ayuda a comprender en qué medida la waḥdat al-wuŷūd $\mathrm{y}$, a su vez, la așālat al-wuŷūd no pueden ser calificadas como una forma de ḥulūl. Mullā Șadrā

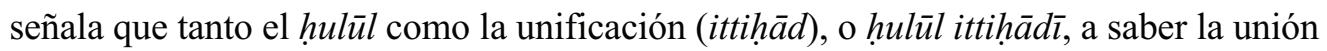
substancial de Dios con los seres contingentes (mumkināt), implican una dualidad (ítnayniyya) en la existencia. Sin embargo, continúa Mullā Șadrā, los seres contingentes no son sino una modalidad o estado ( $\left.\check{s} a^{\prime} n\right)$, un destello radiante (lum 'a) o una luz $(n \bar{u} r)$ del $w u \hat{y} \bar{u} d$. Desde la perspectiva del primado de la existencia, no hay dualidad y por tanto no puede haber hulūl o ittihạad. ${ }^{105}$ Las críticas teológicas que conciben la wah̆dat al-wuŷūd o la hikma muta āliya como una forma de hulül asumen, en general de forma inconsciente, el primado de la quiddidad (așālat al-māhiyya) y hacen caso omiso de las pruebas que apoyan el primado de la existencia (așālat al-wuŷūd).

\section{Conclusiones}

Pese a que asociamos la figura de Ibn 'Arabī con la afirmación de la similitud divina (tašbīh), lo que ha motivado que su metafísica, que recibió el nombre de wahdat alwuŷu $\mathrm{u}$ o unicidad de la existencia, a veces se confunda con el panteísmo, y ello en un contexto religioso en el que Dios es mayoritariamente considerado como transcendente e incomparable, a menudo olvidamos que Ibn 'Arabī afirma de manera radical la transcendencia de la Ipseidad divina. Para Ibn 'Arabī, la similitud es necesaria para no limitar la absolutidad de Dios, de modo que la similitud, conjugada con la incomparabilidad, lejos de introducir un grado de relatividad en Dios, supone la afirmación de un grado ulterior en $\mathrm{Su}$ absolutidad, con lo que la similitud permite transcender la transcendencia. Las acusaciones de hulūl desde sectores neo-ḥanbalīes parten de la asunción acrítica e inconsciente del primado de la quiddidad. La concepción desde estos sectores de que la similitud introduce una limitación en la absolutidad divina - lo que, para Ibn 'Arabī, es de hecho así si no se afirma a la par Su incomparabilidad - no se debe tanto al propio concepto de similitud, según el cual, desde la perspectiva del primado de la existencia, los seres posibles son una teofanía de la existencia, como al hecho de concebir a Dios como una quiddidad y proyectar esta preconcepción en los proponentes de la waḥdat al-wuŷùd.

${ }^{105}$ Ṣadr al-Dīn al-Šīrāzī [Mullā ȘADRĀ]. Kitāb al-mašā ir ir, pp. 53-4, §117. 
Por el contrario, Mullā Șadrā y los filósofos que defienden la aṣălat al-wuŷūd muestran que la existencia de Dios no puede ser diferente de la existencia de los seres contingentes, pues ello implicaría una composición en la existencia en género y diferencia específica, con lo que la existencia no sería necesaria e implicaría un regreso infinito. Si, en cambio, se afirma la așālat al-māhiyya, de modo que Dios y los seres contingentes fueran quiddidades independientes, no podría haber ni cambio, ni, por tanto, universo físico, ni tampoco conocimiento, ni grado alguno de cohesión en la realidad.

En definitiva, la posición que el fiel musulmán adopte ante el par similitudincomparabilidad (tašbīh-tanzīh) estará estrechamente motivada por su posición vital respecto al primado de la existencia y el primado de la quiddidad, pese a que esta posición no necesariamente deba ser consciente. Esta percepción determinará radicalmente su sensibilidad y su forma de ver el mundo. Dependiendo de su posición, el musulmán o bien habitará un cosmos conformado por teofanías (taŷalliyāt), con lo que el cosmos devendrá un texto escrito con los Nombres de Dios, con los atributos de la existencia, o bien habitará un cosmos desprovisto de Su presencia ante el deseo de afirmar la incomparabilidad (tanzīh) y majestad de Dios.

Quizá, a modo de colofón, el poema de Ibn 'Arabī en su Fuṣūṣ al-ḥikam, del cual he citado un extracto con anterioridad, pueda servir de resumen de la articulación de la similitud e incomparabilidad entre Dios y el universo según Ibn 'Arabī:

Si hablas desde la perspectiva de la incomparabilidad (tanzīh), limitas [a Dios] y si hablas desde la perspectiva de la similitud (tašbīh), [Lo] defines.

Si hablas desde ambas perspectivas, has alcanzado la meta y eres imām y señor en los conocimientos sapienciales ( $m a{ }^{\prime}$ 'ārif).

Quien habla añadiendo un par es un asociador [i.e. es idólatra]

Y quien habla afirmando la separación [absoluta de Dios] es un unitario.

Ten cuidado con la similitud si eres un segundo ${ }^{106}$

y ten cuidado con la incomparabilidad si afirmas la separación [absoluta de Dios].

Tú no eres Él, si bien tú eres Él y Lo ves en

la esencia concreta ( 'ayn) de las cosas [a la vez] ausente en la distancia y limitado [en esa esencia concreta]. ${ }^{107}$

\section{José Bellver}

Departamento de Historia de la Filosofía, Estética y Filosofía de la Cultura Universidad de Barcelona

jbellver@ub.edu

\footnotetext{
${ }^{106}$ Probablemente se trate de una alusión al concepto de hulūl en el que el ser contingente es un segundo en la unión substancial.

${ }^{107} \mathrm{IBN}$ 'ARABĪ. Fuṣūṣ al-hikam, p. 70.
} 